\title{
Publisher Correction: Genome-wide analyses of behavioural traits are subject to bias by misreports and longitudinal changes
}

\author{
Angli Xue, Longda Jiang, Zhihong Zhu, Naomi R. Wray (D), Peter M. Visscher (D), Jian Zeng (D) \& Jian Yang
}

Correction to: Nature Communications https://doi.org/10.1038/s41467-020-20237-6, published online 7 January 2021.

The original version of this Article was updated shortly after publication to update the volume number. During the update to the volume, the Article incorrectly gave a publication date of 7 January 2021 and Article number of 6450 in the PDF and HTML version; the correct publication date should have been 12 January 2021 and the correct Article number should have been 20211.

This has now been corrected in both the PDF and HTML versions of the Article.

Published online: 08 February 2021

(c) (i) Open Access This article is licensed under a Creative Commons Attribution 4.0 International License, which permits use, sharing, adaptation, distribution and (C) reproduction in any medium or format, as long as you give appropriate credit to the original author(s) and the source, provide a link to the Creative Commons license, and indicate if changes were made. The images or other third party material in this article are included in the article's Creative Commons license, unless indicated otherwise in a credit line to the material. If material is not included in the article's Creative Commons license and your intended use is not permitted by statutory regulation or exceeds the permitted use, you will need to obtain permission directly from the copyright holder. To view a copy of this license, visit http://creativecommons.org/licenses/by/4.0/.

(c) The Author(s) 2021 